\title{
ARTICLE
}

\section{Thermodynamic data development: solubility method and future research needs (PLENARY)}

\author{
Dhanpat Rai ${ }^{*}$, Mikazu Yui $^{\mathrm{b}}$ and Akira Kitamura \\ ${ }^{a}$ Rai Enviro-Chem, Yachats, Oregon 97498-0784, USA; ${ }^{b}$ Japan Atomic Energy Agency, Iwaki, Fukushima, 970-8026, Japan; ${ }^{c} J a p a n$ \\ Atomic Energy Agency, Tokai, Ibaraki, 319-1184, Japan
}

\begin{abstract}
The solubility method has been used for a long time. Many older published studies used inadequate procedures fraught with deficiencies/problems and resulted in much of the older solubility data being of poor quality. What is surprising however is that there are still articles currently appearing in print describing new studies wherein the most up-to-date procedures have not been used. Discussed herein are important procedures to quantify/control during the use of solubility method to obtain reliable thermodynamic data. These procedures include quantification of hydrogen ion, selection of redox agents to control particular oxidation states for redox sensitive elements such as actinides, and separation of solids from solutions for determining soluble concentrations. Also discussed are 1) ideal procedures/characteristics for conducting solubility studies or evaluating the older literature, 2) an example of how to use the evaluation criteria to judge the quality of older data, 3) some pitfalls in interpreting solubility data, and 4) examples of future research for which the solubility method is ideally suited.
\end{abstract}

Keywords: solubility; future research needs; actinides; redox agents; hydrogen ion concentration method; filtration

\section{Introduction}

The solubility method is one of the best methods and in some cases the only method to obtain reliable thermodynamic data for 1) solubility products of discrete solids, double salts, and solid solutions, 2) complexation constants for various ligands, 3) a wide range of $\mathrm{pH}$ values, 4) metals that form very insoluble solids (e.g. tetravalent actinides), making it difficult to use methods requiring relatively high metal concentrations, 5) ligands (e.g. ethylenediaminetetra-acetic acid (EDTA)) that form such strong complexes with metals (e.g. tetravalent actinides) that it is difficult to obtain reliable values for bare metal ion activities required to determine the complexation constants, 6) solubility-controlling solids in different types of wastes (e.g. radioactive waste glasses [1] and contaminated soils [2]) which cannot be determined by any other currently available techniques because of their inability to quantify all types of solids (e.g. amorphous and solid solutions) when present in trace amounts, and 7) elevated temperatures [3,4].

The solubility method has been used for a long time. Over the years there have been many improvements in the procedures used in this method. In spite of that, a detailed description of the finer points of the method are not described in one source for easy access. Because

*Corresponding author. Email: zzz@abc.co.jp many of the older published studies used inadequate procedures fraught with deficiencies/problems, much of the older data are suspect. However, that is not to say that all old data are bad, but rather that we need to make a concerted effort to determine whether inadequate procedures adversely impacted the quality of the reported data. Surprisingly, even new articles report current studies wherein the most up-to-date procedures have not been used. The objectives of this study are 1) to describe the solubility method, 2) to list desirable criteria of the solubility method so that the reader can recognize which studies have been done in a way that yields quality information, 3) to present an example of how to use the evaluation criteria to judge the quality of older data, 4) to describe some pitfalls in interpreting solubility data, and 5) to provide a few examples of future research for which the solubility method is ideally suited. The examples, supporting citations, and the procedural details discussed herein are all from publications by Rai and coworkers. These are not the only examples; other authors present data that would have made excellent examples. We chose to support the statements mostly with examples from our work for our convenience.

\section{Characteristics of an ideal solubility study}

Discussed here is an ideal solubility study embodying 
the characteristics that must be included when either conducting such studies or evaluating studies reported in the literature (also see [5]). The most important of these characteristics include use of 1) accurate measurement/control of $\mathrm{H}^{+} / \mathrm{OH}^{-}$, 2) accurate measurement/control of redox potential for redox sensitive elements such as actinides, 3) effective techniques to separate solids from solutions for analyses, 4) techniques to achieve low detection limits, 5) low ionic strength solutions, if possible, to achieve accurate $\mathrm{H}^{+} / \mathrm{OH}^{-}$quantification and because high ionic strength solutions have to be diluted before analyses which raises the detection limits, 6) equilibrium approached from both the over- and under-saturation directions (for solids with known rapid precipitation/dissolution kinetics, such as amorphous solids, equilibrium from the under-saturation direction is preferred), 7) extensive characterization of solid and aqueous species, and 8) reliable data interpretational techniques and the use of analog data (if reliable data for such analogs are available) in validating the values.

\subsection{Quantification of hydrogen ion}

Many geologically important minerals and solids of radioactive elements are either oxides or hydroxides. In addition many salts (salts of organic acids such as EDTA and isosaccharinic acid, and most notably salts of inorganic weak acids such as phosphate and carbonate) react with hydrogen, and potentiometric methods are extensively used to determine equilibrium constants in aqueous solutions. Rand et al. [6] point out that the measurement of $\mathrm{H}^{+}$activities/concentrations is fraught with many problems that often have not been taken into account by investigators. Therefore, to develop reliable thermodynamic data for many systems, studies require accurate quantification of $\mathrm{H}^{+} / \mathrm{OH}^{-}$ concentrations/activities. Ultimately, $\mathrm{H}^{+}$activity values are required to obtain thermodynamic data at zero ionic strength for application to systems other than the one used to obtain concentration constants. Therefore, methods are required to directly measure $\mathrm{H}^{+}$activities or $\mathrm{H}^{+}$concentrations along with thermodynamic models (such as Pitzer and SIT) that can be used to convert $\mathrm{H}^{+}$ concentrations to activities. These methods are briefly described here. Much of the discussion in this section is based on Rai and coworkers [5,7].

Most glass electrodes can reliably be used to measure $\mathrm{pH}$ values of relatively dilute solutions $(<\sim 0.1 \mathrm{M}$ ionic strength) in a $\mathrm{pH}$ value range of about $1-12$. If the experiments involve very acidic or very basic conditions, then it is best to use a standard acid or base to adjust $\mathrm{H}^{+}$ or $\mathrm{OH}^{-}$concentrations, and a geochemical code can then be used to calculate the $\mathrm{pH}$ values.

For studies involving $\mathrm{pH}$ it is very often necessary to have data points that not only have a broad range in $\mathrm{pH}$ values but also are evenly spaced along the $\mathrm{pH}$ scale. To obtain such a range in $\mathrm{pH}$ values it is necessary to adjust the $\mathrm{pH}$ of the solid-liquid suspensions multiple times on successive days because there will be a minimum drift in the final experimental $\mathrm{pH}$ values. After this period of $\mathrm{pH}$ adjustments, further adjustments in $\mathrm{pH}$ values must not be made, and the equilibration period is counted from the last $\mathrm{pH}$ manipulation. A similar approach, in addition to the methodology discussed below, should also be taken to adjust $\mathrm{H}^{+}$ concentrations for suspensions involving concentrated electrolytes.

In cases where the studies to obtain thermodynamic data are conducted at high fixed ionic strengths to keep the activity coefficients constant or in salt brines, the measured potentials with glass electrodes are no longer linear and thus electrodes cannot be used to quantify $\mathrm{pH}$. In these cases alternative methods are required to quantify hydrogen ion concentrations/activities. Two reliable methods that can be used to quantify $\mathrm{H}^{+}$ concentrations in concentrated salt solutions using ion selective electrodes (ISE) are: 1) ISEs without liquid junctions, and 2) ISE's with liquid junctions.

Knauss et al. [8] discussed in detail the use of cells without liquid junctions (also see $[9,10]$ ). They used these cells in combination with a variety of ion selective electrodes to directly measure thermodynamic quantities like $a_{\mathrm{HCl}}$ or activity ratios such as $a_{\mathrm{H}+} / a_{\mathrm{Na}+}$ which, in conjunction with analytical concentrations of the ions and the use of SIT or Pitzer models, can be used to calculate the value of the molality of $\mathrm{H}^{+}$. The disadvantages of this method are that it requires an ion selective electrode for the counter ion of interest, thermodynamic models to calculate activity coefficients of the various species, and the assurance that there are no interferences in the measurements made by the ion selective electrodes.

Rai et al. [7] proposed and successfully used a relatively simple procedure for estimating hydrogen ion concentrations $\left(\mathrm{p} \mathrm{C}_{\mathrm{H}^{+}}=-\log _{10}\right.$ of $\mathrm{H}^{+}$concentration) in the $\mathrm{Na}^{+}-\mathrm{Cl}^{-}-\mathrm{SO}_{4}{ }^{2-}-\mathrm{H}_{2} \mathrm{O}$ system using commercially available combination glass electrodes with liquid junctions. The method was tested over a wide range of electrolyte concentrations $\left(0.15\right.$ to $\left.6 \mathrm{~mol} \mathrm{~kg}\left(\mathrm{H}_{2} \mathrm{O}\right)^{-1}\right)$ and $\mathrm{p} C_{\mathrm{H}+}$ values (2 to 12) using pure and mixed $\mathrm{NaCl}$ and $\mathrm{Na}_{2} \mathrm{SO}_{4}$ solutions. A step-by-step procedure is described for modified Gran-type titrations of brines with $\mathrm{HCl}$ and/or $\mathrm{NaOH}$ to determine hydrogen ion concentrations from the measured/observed $\mathrm{pH}$ meter readings. The method can also be adapted to and has been used for other electrolytes including complex brines not specifically investigated by Rai et al. [7]. We recommend using this method because it is easy to use, versatile, and fairly reliable (with an uncertainty of $\pm 0.05 \mathrm{p} C_{\mathrm{H}^{+}}$). A brief description of this method is given below.

From the definitions of EMF of glass electrode and the operational definition of $\mathrm{pH}$ it can be shown that the $\mathrm{p} C_{\mathrm{H}^{+}}$of a given concentrated electrolyte is related to the observed $\mathrm{pH}\left(\mathrm{pH}_{\mathrm{ob}}\right)$ measured with a glass electrode calibrated against standard buffers by Eq. 1 [7], where $\gamma_{\mathrm{H}^{+}}$is the convention dependent molality-scale activity coefficient of $\mathrm{H}^{+}, \Delta \mathrm{E}_{\mathrm{j}}$ the difference in liquid junction potentials between standards and a given electrolyte 
solution.

$$
\mathrm{p} C_{\mathrm{H}^{+}}=\mathrm{pH}_{\mathrm{ob}}+\log _{10} \gamma_{\mathrm{H}^{+}}+\left(\Delta \mathrm{E}_{\mathrm{j}}\right)(\mathrm{F} / 2.303 \mathrm{RT})
$$

Neither $\log _{10} \gamma_{\mathrm{H}^{+}} \operatorname{nor}\left(\Delta \mathrm{E}_{\mathrm{j}}\right)(\mathrm{F} / 2.303 \mathrm{RT})$ is individually measurable, but their combination " $\mathrm{A}$ " $\left[\mathrm{A}=\log _{10} \gamma_{\mathrm{H}^{+}}+\right.$ $\left.\left(\Delta \mathrm{E}_{\mathrm{j}}\right)(\mathrm{F} / 2.303 \mathrm{RT})\right]$ can be measured through modified Gran-type titrations because " $A$ " remains constant in a given electrolyte solution as the $\mathrm{H}^{+}$concentration changes. The constant $\mathrm{A}$ is then obtained by a modified Gran titration procedure in which the moles of added free acid per liter are plotted against $\mathrm{H}_{\mathrm{ob}}{ }^{+}$(i.e., $10^{-\mathrm{pH}} \mathrm{ob}$ ). The logarithm of the slope of this curve provides the correction factor " $\mathrm{A}$ " needed to convert the $\mathrm{pH}_{\mathrm{ob}}$ reading to $\mathrm{p}_{\mathrm{H}+}$ using Eq. 2 .

$$
\mathrm{p} C_{\mathrm{H}^{+}}=\mathrm{pH}_{\mathrm{ob}}+\mathrm{A}
$$

The experimental procedure to obtain the values of factor " $A$ " is described in detail by Rai et al. [7]. In the past some authors have used the same concentrated electrolyte in the salt bridge as the electrolyte used in the experiments to minimize or eliminate the liquid junction potentials. However, this does not eliminate the need to determine the value of the correction factor " $\mathrm{A}$ " to accurately determine the $\mathrm{H}^{+}$concentrations. This is because the correction factor depends not only on the liquid junction potentials but also on the activity coefficients of $\mathrm{H}^{+}$, and the latter can be significantly different than in the buffer solutions. The calculation of correction factors for electrolytes that contain perchlorate, react with $\mathrm{H}^{+}$or with $\mathrm{OH}^{-}$requires that the amount of $\mathrm{H}^{+}$or $\mathrm{OH}^{-}$consumed by these side reactions be accurately determined. For details of handling these types of electrolytes see Rai et al. [7].

This procedure has been successfully used for a large number of relatively dilute to concentrated (as high as 9 mol $\left.\mathrm{kg}\left(\mathrm{H}_{2} \mathrm{O}\right)^{-1}\right)$ simple electrolytes, mixtures of electrolytes, and synthetic brines; examples are $\mathrm{NaCl}$ [7,11,12-14], $\mathrm{NaClO}_{4}$ [14], $\mathrm{CaCl}_{2}$ [11,15], $\mathrm{MgCl}_{2}$ [13], $\mathrm{Na}_{2} \mathrm{SO}_{4}$ [7], and synthetic brines containing $\mathrm{Na}, \mathrm{K}, \mathrm{Ca}$, $\mathrm{Mg}, \mathrm{Cl}, \mathrm{SO}_{4}$, and $\mathrm{Br}[16]$.

\subsection{Selection of redox agents for controlling oxidation states}

One of the big challenges in developing reliable data for redox sensitive elements is controlling redox potentials/oxidation states during experimentation. Several actinides ( $\mathrm{U}, \mathrm{Np}$, and $\mathrm{Pu}$ ) and other elements important in nuclear waste disposal (e.g., Tc and Se) exhibit multiple oxidation states in the environmental range of $\mathrm{pH}$ and $\mathrm{E}_{\mathrm{h}}$ values. Therefore experimental evaluations involving these different oxidation states require these specific oxidation states to be stable throughout the duration of experiments. One of the best ways to assure this is through the use of appropriate redox agents along with the capability to fix oxygen partial pressures during the experiments. This subsection is devoted to a brief discussion of various redox agents and their required attributes as well as methods to control oxygen partial pressures.

Oxygen partial pressures have traditionally been managed using glove-boxes. The use of pre-purified inert gasses (e.g. $\mathrm{N}_{2}(\mathrm{~g}), \operatorname{Ar}(\mathrm{g})$ ) assures that the oxygen can be achieved at about $10 \mathrm{ppm}$, which translates to about $10^{-7}$ atmospheres of $\mathrm{O}_{2}(\mathrm{~g})$. Although this is a great improvement over what is present in air $\left(\sim 10^{-0.68}\right.$ atmospheres), it is not low enough to maintain many of the reduced oxidation states of different actinides (e.g., it would require $\sim 10^{-65}$ atm. for maintaining $\mathrm{U}(\mathrm{IV})$ and $\sim$ $10^{-42}$ atm. for $\left.\mathrm{Np}(\mathrm{IV})\right)$.

We have been able to maintain very low oxygen partial pressures, close to what is required for maintaining $\mathrm{U}(\mathrm{IV})$, by passing glove box air through distilled water and Fe-powder suspensions and passing this over a hygroscopic compound to remove moisture that can be problematic for operation of the chamber. It should be mentioned that simply fixing the oxygen partial pressures is not sufficient to maintain the required oxidation state; it must be accompanied by the addition of appropriate redox agents in sample suspensions. In addition, the sample tubes must always be kept sealed and open to glove box atmosphere for as short a time as possible to make sure that traces of oxygen are not inadvertently introduced into the sample tubes.

Many different aspects of redox agents need to be understood. These include 1) mode of operation and desirable attributes, 2) available data for redox agents, 3) selection criteria, and 4) experimentally evaluated redox agents for redox sensitive radioactive elements. The modes of operation of redox agents include 1) interacting with oxygen so that inadvertent addition of oxygen into samples does not cause oxidation of the element of interest, 2) acting as an oxidant or reductant for the element of interest, and/or 3) acting as a redox buffer which can maintain specific $E_{h}$ value for maintaining a given oxidation state.

Desirable redox agents are those that 1) are kinetically active, 2) do not form strong complexes with elements of interest or if they do thermodynamic data for these interactions are available, 3) do not change $\mathrm{pH}$ values of the systems, 4) are effective in the range of $\mathrm{pH}$ values of interest, 5) are effective at room temperatures, and 6) are soluble for enhanced reactivity. Information regarding available redox agents is reported in several publications $[17,18]$.

It needs to be stated that a given redox couple/reaction can act as a reducing or oxidizing agent; it depends on the relative redox potentials of the two couples in question. If the reduction potential of the couple is lower than another couple it then acts as a reducing agent. The effectiveness of the redox/oxidizing agent depends not only on its relative potential but also on the kinetics of reaction. In other words, just because a redox agent has a desirable potential, it does not mean that it is effective under all conditions. For example, $\mathrm{H}_{2}(\mathrm{~g})$, Fe-powder, and $\mathrm{Pb}$ and $\mathrm{Zn}$ metals all have low enough potentials to reduce $\mathrm{U}(\mathrm{VI})$ to $\mathrm{U}(\mathrm{IV})$, but $\mathrm{H}_{2}(\mathrm{~g})$ requires higher temperatures and is effective at room 
temperature only under very acidic conditions [19] and $\mathrm{Pb}$ and $\mathrm{Zn}$ metals were not as effective [20] as some of the other agents tested, Fe-powder is effective in dilute alkaline conditions but is not effective in brines [19,21]. It is a priori difficult to know, based only on the relative redox potentials, whether a given redox agent will be effective in controlling a given oxidation state. Therefore over the years we have experimentally evaluated a large number of redox agents for maintaining different oxidations states of different elements (U, Np, Pu and Tc). The tested redox agents include $\mathrm{Na}_{2} \mathrm{~S}_{2} \mathrm{O}_{4}$ for $\mathrm{U}(\mathrm{IV}), \quad \mathrm{Np}(\mathrm{IV}), \quad \mathrm{Tc}(\mathrm{IV})$ [12,20,22-27], Fe-powder for U(IV), Np(IV), Pu(III) $[16,19,21,22,25,28], \quad \mathrm{EuCl}_{2}$ for U(IV) and Tc(IV) $[4,12,13,19], \mathrm{NH}_{2} \mathrm{OH} . \mathrm{HCl}$ for $\mathrm{Np}$ (IV) $[25,29], \mathrm{NH}_{2} \cdot \mathrm{NH}_{2}$ for $\mathrm{Np}(\mathrm{IV}), \mathrm{Tc}(\mathrm{IV})[12,25], \mathrm{Ni} / \mathrm{Pb} / \mathrm{Zn}$ metals for $\mathrm{Np}(\mathrm{IV})$, $\mathrm{U}(\mathrm{IV})$ [20,22], $\mathrm{NaOCl}$ for $\mathrm{Pu}(\mathrm{VI})$ [30], $\mathrm{Fe}(\mathrm{II})$ for $\mathrm{Pu}(\mathrm{III})$ [31], $\mathrm{Cu}(\mathrm{I}) / \mathrm{Cu}(\mathrm{II})$ buffer for $\mathrm{Np}(\mathrm{IV})$ [32], and hydroquinone for $\mathrm{Pu}(\mathrm{III})$ [31]. This list is provided as a guide for possible selection of redox agents for future studies.

\subsection{Separating solids from solutions}

The stability of colloidal suspensions depends on factors such as colloid size, $\mathrm{pH}$, and ionic strength [33-35]. For examples, 1) Rai et al. [33] report that $\mathrm{Pu}(\mathrm{IV})$ polymeric suspensions are stable for six months at $\mathrm{pH} \mathrm{2,} \mathrm{but} \mathrm{less} \mathrm{than} \mathrm{one} \mathrm{percent} \mathrm{of} \mathrm{the} \mathrm{total} \mathrm{polymer} \mathrm{is}$ found in suspension at $\mathrm{pH} \mathrm{6}$, and 2) Rai et al. [34] show that Am colloids were absent in low $\mathrm{pH}$ suspensions (similarity of concentrations in unfiltered and $0.0018 \mu \mathrm{m}$ filtrates) but colloids contributed up to about three orders of magnitude higher Am concentrations at $\mathrm{pH}$ values $>7$, and 3) Cho et al. [35] report that $\mathrm{Zr}$ colloids are formed within a few minutes after the solubility limit is exceeded and they are stable for several months. It is a priori difficult to predict the existence of colloids in a given system. Centrifugation alone at as high as 6000 $\mathrm{G}$ does not provide necessary confidence that the solutions thus obtained are colloid-free [36]. To be confident that the solutions for analyses are free of colloids, it is absolutely necessary to filter the equilibrated suspensions through very fine pore-sized membrane filters.

Several precautions need to be taken to make certain the filters are not responsible for altering the soluble concentrations. These precautions must include filter pretreatment procedures to guarantee that 1) there is no adsorption of the element of concern by the filters or the filtration containers, 2) filters do not alter the $\mathrm{pH}$ or $\mathrm{E}_{\mathrm{h}}$ of the solutions during filtration, and 3) filters do not contribute to the concentration of the element of concern (e.g., $\mathrm{C}$ in some cases). Rai and coworkers (e. g., see $[37,38])$ have outlined and described several steps to mitigate the possible deleterious effects of the filter. These steps include 1) centrifuge the aqueous suspensions and use supernatant (from middle section to avoid very fine colloids that may be present in the top layer of supernatant) for filtration to minimize the amount of colloidal material that may affect the efficiency of the filters, 2) soak the filters in solutions made of the same $\mathrm{pH} / \mathrm{E}_{\mathrm{h}}$ and background electrolyte as the given samples, and 3) discard the first filtrate in order to saturate the potential adsorption sites on the filters and the filtration equipment, and 4) use the second filtrate for analysis.

\subsection{Selecting and characterizing solid phase and an approach to equilibrium}

Several different criteria are used in selecting an appropriate solid phase for study. Characteristics of solid phases should include those whose 1) solubility product is unknown or uncertain and needs confirmation, 2) solubility product is known and has reasonably low solubility and which is desirable to use for determining complexation constants of the metal ion of the solid phase with another ligand, and 3) solubility can be approached from both the over-saturation and under-saturation directions (solid phases may be crystalline or amorphous and pure phases or solid solutions). If solubility cannot be approached from both the over- and under-saturation directions at normal atmospheric conditions then experimental protocol must be changed (e.g., conducting experiments at higher temperatures) to accommodate this requirement. If the solid phase shows rapid precipitation/dissolution kinetics (as is the case with many amorphous phases), then the solubility should preferably be conducted from the under-saturation direction to avoid uncertainties due to inadequately separating solids from solutions when approached from over-saturation direction. Many different techniques either alone or in combination (e.g., X-ray diffraction, EXAFS, SEM, TEM, spectrophotometric and chemical analyses) can be used to characterize the solid phase. No attempt will be made here to describe these techniques except to emphasize that the solid phases must be thoroughly characterized using the best methods available at the start and end of the solubility studies to make sure the nature of equilibrating solid phase is known. The characterization must cover different ranges in which the observed solubility changes as a function of a given variable.

Care must be taken in selecting the amount of the solid phase to be used in studies. It should be large enough that 1) it will exceed the maximum amount that may dissolve under a given set of conditions, 2) there should be sufficient left for solid phase characterization after that amount is dissolved, and 3) in some cases the solid phase may act as an adsorbent for the ligand being studied (e.g., $\mathrm{Fe}(\mathrm{OH})_{3}(\mathrm{am})$ for EDTA [39]); in those cases it is necessary to scale the solid phase to a smaller amount to minimize the impact on the ligand concentration and to make certain that the concentration of the ligand will not be impacted significantly due to adsorption by the solid phase. 
Table 1. Selected characteristics of $\mathrm{ZrO}_{2}(\mathrm{am})$ solubilities in relatively acidic solutions, where $\mathrm{Y}$ stands for yes and $\mathrm{N}$ for No for the presence of a given ideal study characteristic (after Rai et al. 2018, in press in J. Solution Chem.).

\begin{tabular}{|c|c|c|c|c|c|c|c|}
\hline Reference & $\mathrm{I}_{\mathrm{M}}$ & Low I & $\begin{array}{l}\text { Low } \\
\text { Det. }\end{array}$ & Filter & $\begin{array}{l}\text { Equil. from } \\
\text { (Under-Sat.) }\end{array}$ & $\begin{array}{l}\text { Accurate } \\
\mathrm{pH} / \mathrm{pC}_{\mathrm{H}}^{+}\end{array}$ & $\begin{array}{l}\text { Analogous } \\
\text { to Hf }\end{array}$ \\
\hline Ideal Study & Dil. & $\mathrm{Y}$ & $\mathrm{Y}$ & $\mathrm{Y}$ & $\mathrm{Y}$ & $\mathrm{Y}$ & $\mathrm{Y}$ \\
\hline Kovalenko and Bogdasarov [45] & Dil. & $\mathrm{Y}$ & $\mathrm{Y}$ & $\mathrm{N}$ & $\mathrm{Y}$ & $\mathrm{Y}$ & $\mathrm{Y}$ \\
\hline \multirow[t]{2}{*}{ Bilinski et al. [41] } & Dil. & $\overline{\mathrm{Y}}$ & $\mathrm{N}$ & $\mathrm{N}$ & $\mathrm{N}$ & $\overline{\mathrm{Y}}$ & $\mathrm{N}$ \\
\hline & $1.0 \mathrm{NaClO}_{4}$ & $\mathrm{~N}$ & $\mathrm{~N}$ & $\mathrm{~N}$ & $\mathrm{~N}$ & $\mathrm{~N}$ & $\mathrm{~N}$ \\
\hline \multirow[t]{4}{*}{ Veyland [42] } & $0.2 \mathrm{NaNO}_{3}$ & $?$ & $\mathrm{~N}$ & $\mathrm{~N}^{\mathrm{a}}$ & $\mathrm{N}$ & $?$ & $\mathrm{~N}$ \\
\hline & $0.5 \mathrm{NaNO}_{3}$ & $\mathrm{~N}$ & $\mathrm{~N}$ & $\mathrm{~N}^{\mathrm{a}}$ & $\mathrm{N}$ & $\mathrm{N}$ & $\mathrm{N}$ \\
\hline & $1.0 \mathrm{NaNO}_{3}$ & $\mathrm{~N}$ & $\mathrm{~N}$ & $\mathrm{~N}^{\mathrm{a}}$ & $\mathrm{N}$ & $\mathrm{N}$ & $\mathrm{N}$ \\
\hline & $2.0 \mathrm{NaNO}_{3}$ & $\mathrm{~N}$ & $\mathrm{~N}$ & $\mathrm{~N}^{\mathrm{a}}$ & $\mathrm{N}$ & $\mathrm{N}$ & $\mathrm{N}$ \\
\hline Ekberg et al. [46] & $1.0 \mathrm{NaClO}_{4}$ & $\mathrm{~N}$ & $\mathrm{Y}$ & $\mathrm{N}$ & $\mathrm{Y}$ & $\mathrm{N}$ & $\mathrm{N}$ \\
\hline
\end{tabular}

\section{An example using solubility criteria to evaluate literature data}

In 2005 the Nuclear Energy Agency [40] evaluated Zr hydrolyses data. We rated the studies considered by Brown et al. [40] in their analyses (Table 1) according to the criteria developed above. Two studies [41,42] that were the basis for a major part of Brown et al.'s [40] $\mathrm{Zr}-\mathrm{OH}$ model did not meet any of the ideal solubility criteria. To fit these divergent and poor quality data Brown et al. [40] used polynuclear species $\left[\mathrm{Zr}_{4}(\mathrm{OH})_{16}(\mathrm{aq}), \mathrm{Zr}_{4}(\mathrm{OH})_{15}{ }^{+}, \mathrm{Zr}_{3}(\mathrm{OH})_{9}{ }^{3+}\right]$ which cannot be differentiated from the corresponding mononuclear species $\left[\mathrm{Zr}(\mathrm{OH})_{4}(\mathrm{aq}), \mathrm{Zr}(\mathrm{OH})_{3}^{+}, \mathrm{ZrOH}^{3+}\right]$ based on solubility studies and should not have been considered. Because of their inclusion of polynuclear species into their model, their reported values for the formation of $\mathrm{Zr}(\mathrm{OH})_{4}(\mathrm{aq})$ and $\mathrm{Zr}(\mathrm{OH})_{6}{ }^{2-}$, and the solubility product of $\mathrm{ZrO}_{2}(\mathrm{am})$ are five to nine orders of magnitude different than the corresponding values for the analogous $\mathrm{Hf}$ reactions [43], whereas reported equilibrium constant values for both the $\mathrm{Hf}$ and $\mathrm{Zr}$ reactions with $\mathrm{Cl}^{-}, \mathrm{NO}_{3}{ }^{-}$, and $\mathrm{SO}_{4}{ }^{2-}[44]$ as well as with $\mathrm{F}^{-}$and $\mathrm{CO}_{3}{ }^{2-}$ are very similar. Recently Altmaier et al. [11] conducted extensive $\mathrm{ZrO}_{2}(\mathrm{am})$ solubility studies in a large number of electrolytes that meet nearly all ideal solubility study criteria. When these data along with low $\mathrm{pH}$ data of Kovalenko and Bogdasarov [45] (Table 1) and the solubility data (Altmaier et al. [11], Ekberg et al. [46], and Sheka and Pevzner [47]) in super-alkaline solutions that meet most attributes are reinterpreted using mononuclear species, they all provide a set of values (Rai et al. 2018, in press in J. Solution Chem.) for the formation of $\mathrm{Zr}(\mathrm{OH})_{4}(\mathrm{aq})$ and $\mathrm{Zr}(\mathrm{OH})_{6}{ }^{2-}$, and the solubility product of $\mathrm{ZrO}_{2}(\mathrm{am})$ that are very consistent with the analogous $\mathrm{Hf}$ values and lend credence to the values thus calculated. The main point of this discussion is to demonstrate how the ideal solubility criteria are useful in evaluating the quality of previously published solubility data.

\section{Selected aspects of interpreting solubility data}

Reliable models (such as SIT and Pitzer) should be used for data interpretation, and reliable data obtained by all methods (e. g., solubility, solvent extraction, ion exchange, potentiometric) should be reinterpreted collectively to develop reliable values for thermodynamic constants. There may be several specific cases in which solubility data may be misinterpreted inadvertently. We present two cases below wherein the solubility data may be/is prone to be misinterpreted.

One case involves studies with a fairly insoluble $\mathrm{HfO}_{2}$ (c) solid [38]. It is important that the studies are carried out in a wide range of $\mathrm{pH}$ values; otherwise incorrect conclusions may be drawn from the data. If Rai et al. [38] had conducted this study at $\mathrm{pH}$ values no lower than 1.0, based on the similarity of $\mathrm{Hf}$ concentrations at different equilibration periods (ranging from 8 to 129 days) (Figure 1) they would have come to the wrong conclusion that the solubility-controlling solid is $\mathrm{HfO}_{2}(\mathrm{c})$. However, they conducted this study in a range of $\mathrm{pH}$ values extending down to -0.32 which showed that Hf concentrations are nearly constant in the $\mathrm{pH}$ region -0.32 to 1.0 , indicating that the solubility-controlling solid is not $\mathrm{HfO}_{2}$ (c) (Figure 1). This is true because 1) there is a sufficient amount of total solid that the solubility would have continued with a slope of +3 with the decrease in $\mathrm{pH}$ as is the case in the $\mathrm{pH}$ region between 1 and 2 and $\log _{10}$ [Hf] would have reached - 2.3, and 2) several other solid pretreatments/conditions prior to use in studies (e.g., decrease in the amount of the solid phase, heating the solid to $1400{ }^{\circ} \mathrm{C}$, acid washing the solid [38] showed a decrease in the Hf concentrations that are independent of $\mathrm{pH}$ in the $\mathrm{pH}$ region -0.32 to 1.0 ; this all points to the fact that $\mathrm{HfO}_{2}(\mathrm{c})$ is not the solubility-controlling solid but instead it is a small amount of impurity of less crystalline $\mathrm{HfO}_{2}(\mathrm{lc})$ associated with the bulk $\mathrm{HfO}_{2}(\mathrm{c})$. These treatments described above should not have resulted in decrease in $\mathrm{Hf}$ concentrations as compared to the untreated solid if the solubility-controlling solid had 
truly been $\mathrm{HfO}_{2}(\mathrm{c})$. This is not a situation unique to $\mathrm{HfO}_{2}$ (c) but rather is consistent with a more general observation that the crystal mineral surfaces are often structurally and or compositionally imperfect, and the effect of these imperfections is quantifiable with the solubility method. This behavior is observed for $\mathrm{ThO}_{2}(\mathrm{c})$ and $\mathrm{UO}_{2}(\mathrm{c})$ as well $[3,4]$.

The other case deals with the observed $\mathrm{pH}$ independent concentrations (in the $\mathrm{pH}$ region of around 7) for many fairly insoluble oxides/hydroxides of tetravalent elements (Th, U(IV), Np(IV), Pu(IV), Sn, Hf, and $\mathrm{Zr}$ ) and trivalent actinides. The observed $\mathrm{pH}$-independent concentrations according the generalized reaction for tetravalent ions $\left[\mathrm{MO}_{2}(\mathrm{am}) \rightleftharpoons\right.$ $\left.\mathrm{M}(\mathrm{OH})_{4}(\mathrm{aq})\right]$ are often used to assign/derive a definitive value for the formation of $\mathrm{M}(\mathrm{OH})_{4}(\mathrm{aq})$. The $\mathrm{pH}$-independent concentrations thus observed result from detection limits for $\mathrm{M}$, presence of colloids, presence of a finite amount of less crystalline solid as impurities when dealing with bulk fully crystalline solid, and in the case of redox sensitive elements such as $\mathrm{U}(\mathrm{IV}), \mathrm{Np}(\mathrm{IV})$, and $\mathrm{Pu}(\mathrm{IV})$ are due to inadequate methods of controlling the redox potentials during solubility studies and the presence of a finite amount of a more soluble oxidation state. These reactions can be used to set upper limit concentrations which are needed for repository evaluations, but should not be defined as a specific value but rather an upper limit value as we portray in many of our publications $([4,37,43])$. This is especially a problem when these values are used as definitive values (e.g., see [48]) to calculate/determine values for other hydrolyses/ligand reactions.

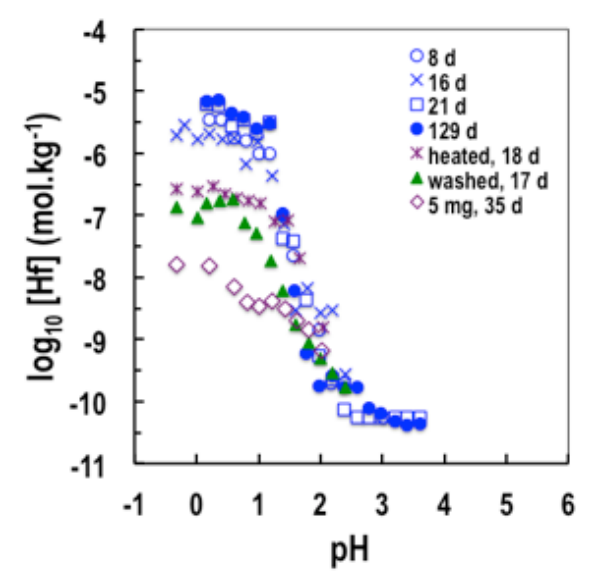

Figure 1. Aqueous Hf concentrations from $0.0036 \mu \mathrm{m}$ as a function of $\mathrm{pH}$ and equilibration periods ranging from 8 to 129 days from $35.5 \mathrm{mg} \mathrm{HfO}_{2}$ (c) suspensions in 35 milliliters of solution. Hf concentrations from $\mathrm{HfO}_{2}$ (c) suspensions when the original solid phase was heated to $1400{ }^{\circ} \mathrm{C}$, acid washed, or the amount of the solid was decreased to $5 \mathrm{mg}$ prior to equilibrations (after Rai et al. [38]).

\section{Future research needs}

Studies are warranted if 1) no data are available for the given system, 2) reported values disagree and/or vary a great deal, 3) existing data are very limited, 4) existing data were obtained using unreliable methods, and/or 5) reliable values cannot be obtained from reinterpretation/critical-review of existing data. It is clear from the above discussion that future research needs can only be outlined based on extensive knowledge and review of the existing data.

The available thermodynamic data for two systems we recently critically reviewed and can recommend future research needs are: 1) thermodynamic data in predicting leachability of actinides from actinide-containing glasses [1], and 2) isosaccharinate reactions with actinides [49]. The research needs for these two systems are discussed below.

Thermodynamic data can be used to predict environmental behavior of radioactive elements disposed in geologic environments in different waste forms, such as glasses. The glasses are chemically very complex, containing only minor amounts of radioactive elements, and thus provide experimental challenges to determine the nature of the radioactive element solubility-controlling solids. To date most glass studies are related to determining stability behavior of the glass matrix. In their comprehensive review Rai et al. [1] proposed and showed, based on rather limited available experimental solubility data with actual glasses, that thermodynamic data can be used to determine maximum leachable actinide concentrations by identifying solubility-controlling actinide solids. They also point out that the solubility method is the only method that is well suited for these determinations because 1) glasses are chemically complex, 2) micro-quantities of radioactive solid phases that may be present are not amenable to quantification by the available analytical techniques, and 3) solid phases in glasses may be crystalline, amorphous, and/or solid solutions and thus it is a priori difficult to determine the nature of the solubility-controlling solids. Rai et al. [1] report several different tetravalent (Th, $\mathrm{U}, \mathrm{Np}, \mathrm{Pu})$ and trivalent $(\mathrm{Pu}$ and $\mathrm{Am})$ actinide solids that are expected to control actinide concentrations leached from actinide-doped glasses. Based on available data for complex glasses they showed that the trivalent actinide/lanthanide concentrations appear to be controlled by solid solutions of these elements. However, thermodynamic data for solid solutions $\left[(\mathrm{An}(\mathrm{III}), \mathrm{Ln})(\mathrm{OH})_{3}(\mathrm{c}) ;(\mathrm{An}(\mathrm{III}), \mathrm{Ln}) \mathrm{PO}_{4}(\mathrm{c})\right]$ based on pure systems are not available for confirmations. These data are sorely needed because solid solutions, depending on the mole fraction of the given element, can decrease the solubility by many orders of magnitude compared to the pure phase.

Isosaccharinic acid is expected to be one of the important degradation products of cellulose, disposed in low-level nuclear waste repositories, that is known to form strong complexes with actinides. Rai et al. [49] recently critically reviewed the available data for the isosaccharinate reaction with actinides. This review pointed out that reliable values for isosaccharinate complexes with $\mathrm{Pu}(\mathrm{IV}), \mathrm{U}(\mathrm{IV})$, and $\mathrm{Am}(\mathrm{III})$ are needed 
for confirmation of the values they estimate based on sparse data for these systems, and that the best method to obtain these values is through the solubility of $\mathrm{PuO}_{2}(\mathrm{am}), \mathrm{UO}_{2}(\mathrm{am})$, and $\mathrm{Am}(\mathrm{OH})_{3}(\mathrm{am})$ as a function of $\mathrm{pH}$ and isosaccharinate concentrations.

\section{Acknowledgements}

This manuscript is a result of collaborative efforts between Japan Atomic Energy Agency (JAEA) and Rai Enviro-Chem. The senior author gratefully acknowledges the financial support provided by JAEA for this work.

\section{References}

[1] D. Rai, M. Yui, A. Kitamura and B. Grambow, Thermodynamic approach for predicting actinide and rare earth concentrations in leachates from radioactive waste glasses, J. Solution Chem. 40 (2011), pp. 1473-1504.

[2] D. Rai and R.W. Szelmeczka, Aqueous behavior of chromium in coal fly ash, J. Environ. Qual. 19 (1990), pp. 378-382.

[3] D. Rai, D.A Moore, C.S. Oakes and M. Yui, Thermodynamic model for the solubility of thorium dioxide in the $\mathrm{Na}^{+}-\mathrm{Cl}^{-}-\mathrm{OH}^{-}-\mathrm{H}_{2} \mathrm{O}$ system at 23 and 90 degrees C, Radiochim. Acta 88 (2000), pp. 297-306.

[4] D. Rai, M. Yui and D.A. Moore, Solubility and solubility product at $22^{\circ} \mathrm{C}$ of $\mathrm{UO}_{2}(\mathrm{c})$ precipitated from aqueous U(IV) solutions, J. Solution Chem. 32 (2003), pp. 1-17.

[5] D. Rai and M. Yui, Thermodynamic Data Development Using the Solubility Method, JAEA-Technology 2013-002, Japan Atomic Energy Agency, (2013).

[6] M.H. Rand, J. Fuger, I. Grenthe, V. Neck and D. Rai, Chemical Thermodynamics of Thorium. Nuclear Energy Agency, Organization for Economic Co-Operation and Development, Paris, (2008).

[7] D. Rai, A.R. Felmy, S.P. Juracich and L. Rao, Estimating the Hydrogen Ion Concentration in Concentrated $\mathrm{NaCl}$ and $\mathrm{Na}_{2} \mathrm{SO}_{4}$ Electrolytes. SAND94-1949, Sandia National Laboratory, (1995).

[8] K.G. Knauss, T.J. Wolery and K.J. Jackson, A new approach to measuring $\mathrm{pH}$ in brines and other concentrated electrolytes, Geochim. Cosmochim. Acta 54 (1990), pp. 1519-1523.

[9] K.G. Knauss, T.J. Wolery and K.J. Jackson, Reply to comment by R. E. Mesmer on 'A new approach to measuring $\mathrm{pH}$ in brines and concentrated electrolytes'. Geochim. Cosmochim. Acta 55, (1991), pp. 1177-1179.

[10]R.E. Mesmer, Comments on 'A new approach to measuing $\mathrm{pH}$ in brines and other concentrated electrolytes' by K. G. Knauss, T. J. Wolery, and K.
J. Jackson. Geochim. Cosmochim. Acta 55 (1991), pp. 1175-1176.

[11]M. Altmaier, V. Neck and Th. Fanghanel, Solubility of $\mathrm{Zr}(\mathrm{IV}), \mathrm{Th}(\mathrm{IV})$ and $\mathrm{Pu}(\mathrm{IV})$ hydrous oxides in $\mathrm{CaCl}_{2}$ solutions and the formation of ternary Ca-M(IV)-OH complexes, Radiochim. Acta 96 (2008), pp. 541-550.

[12]N.J. Hess, Y. Xia, D. Rai and S.D. Conradson, Thermodynamic model for the solubility of $\mathrm{TcO}_{2} \cdot \mathrm{xH}_{2} \mathrm{O}(\mathrm{am})$ in the aqueous $\mathrm{Tc}(\mathrm{IV})-\mathrm{Na}^{+}-$ $\mathrm{H}^{+}-\mathrm{Cl}^{-}-\mathrm{OH}^{-}-\mathrm{H}_{2} \mathrm{O}$ system, J. Solution Chem. 33 (2004), pp. 199-226.

[13]D. Rai, A.R. Felmy, S.M. Sterner, D.A. Moore, M.J. Mason and C.F. Novak, The solubility of Th(IV) and U(IV) hydrous oxides in concentrated $\mathrm{NaCl}$ and $\mathrm{MgCl}_{2}$ solutions, Radiochim. Acta 79 (1997), pp. 239-247.

[14]D. Rai, D.A. Moore, A.R. Felmy, G.R. Choppin and R.C. Moore, Thermodynamics of $\mathrm{PuO}_{2}{ }^{+}-\mathrm{Na}^{+}-\mathrm{Cl}^{-}-\mathrm{ClO}_{4}{ }^{-}-\mathrm{OH}^{-}-\mathrm{H}_{2} \mathrm{O}$ system: Use of $\mathrm{NpO}_{2}^{+}$Pitzer ion-interaction parameters for $\mathrm{PuO}_{2}^{+}$, Radiochim. Acta 89 (2001), pp. 491-498.

[15]D. Rai, A.R. Felmy, N.J. Hess, V.L. LeGore and D.E. McCready, Thermodynamics of the $\mathrm{U}(\mathrm{VI})-\mathrm{Ca}^{2+}-\mathrm{Cl}^{-}-\mathrm{OH}^{-}-\mathrm{H}_{2} \mathrm{O}$ system: Solubility product of becquerelite, Radiochim. Acta 90 (2002), pp. 495-503.

[16]A.R. Felmy, D. Rai, J.A. Schramke and J.L. Ryan, The solubility of $\mathrm{Pu}(\mathrm{OH})_{3}$ in dilute solution and in high-ionic-strength chloride brines, Radiochim. Acta 48 (1989), pp. 29-35.

[17]T.W. Newton and T.W, The Kinetics of the Oxidation-reduction Reactions of Uranium, Neptunium, Plutonium, and Americium in Aqueous Solutions, Technical Information Center, Office of Public Affairs, U. S. Energy Research and Development Administration, Oakridge, TN (1975).

[18]R.C. Weast (ed.), Handbook of Chemistry and Physics, 53rd edition, The Chemical Rubber Co., Cleveland, OH, (1972).

[19]D. Rai, A.R. Felmy and J.L. Ryan, Uranium(IV) hydrolysis constants and solubility product of $\mathrm{UO}_{2} * \mathrm{xH}_{2} \mathrm{O}(\mathrm{am})$, Inorg. Chem. 29 (1990) pp. 260-264.

[20]J.L. Ryan and D. Rai, The solubility of uranium (IV) hydrous oxide in sodium hydroxide solutions under reducing conditions, Polyhedron 2 (1983), pp. 947-952.

[21]Y. Xia, L. Rao, D. Rai and A.R. Felmy, Determining the distribution of $\mathrm{Pu}, \mathrm{Np}$, and $\mathrm{U}$ oxidation states in dilute $\mathrm{NaCl}$ and synthetic brine solutions, J. Radioanal. Nucl. Chem. 250 (2001) pp. 27-37.

[22]D. Rai and J.L. Ryan, Neptunium (IV) hydrous oxide solubility under reducing and carbonate conditions, Inorg. Chem. 24 (1985), pp. 247-251.

[23]D. Rai, A.R Felmy, N.J. Hess, D.A. Moore and M. Yui, A thermodynamic model for the solubility of $\mathrm{UO}_{2}(\mathrm{am})$ in the aqueous $\mathrm{K}^{+}-\mathrm{Na}^{+}-\mathrm{HCO}_{3}^{-}$ 
$\mathrm{CO}_{3}{ }^{2-}-\mathrm{OH}^{-}-\mathrm{H}_{2} \mathrm{O}$ system, Radiochim. Acta 82 (1998), pp. 17-25.

[24]D. Rai, L. Rao and D.A. Moore, The influence of issosachharinic acid on the solubility of $\mathrm{Np}$ (IV) hydrous oxide, Radiochim. Acta 83 (1998), pp. 09-13.

[25]D. Rai, N.J. Hess, A.R. Felmy, D.A. Moore and M. Yui, A thermodynamic model for the solubility of $\mathrm{NpO}_{2}(\mathrm{am})$ in the aqueous $\mathrm{K}^{+}-\mathrm{HCO}_{3}{ }^{-}-\mathrm{CO}_{3}{ }^{2-}-\mathrm{OH}^{-}$ $-\mathrm{H}_{2} \mathrm{O}$ system, Radiochim. Acta 84 (1999), pp. 159-169.

[26]D. Rai, N.J. Hess, Y. Xia, L. Rao, H.M. Cho, R.C. Moore and L.R. Van Loon, Comprehensive thermodynamic model applicable to highly acidic to basic conditions for isosaccharinate reactions with $\mathrm{Ca}(\mathrm{II})$ and $\mathrm{Np}(\mathrm{IV})$, J. Solution Chem. 32 (2003), pp. 665-689.

[27]D. Rai, N.J. Hess, M. Yui, A.R. Felmy and D.A. Moore, Thermodynamics and solubility of $\left(\mathrm{U}_{\mathrm{x}} \mathrm{Np}_{1-\mathrm{x}}\right) \mathrm{O}_{2}(\mathrm{am})$ solid solution in the carbonate system, Radiochim. Acta 92 (2004), pp. 527-535.

[28]D. Rai, A.R. Felmy, D.A. Moore and M.J. Mason, The solubility of Th(IV) and U(IV) hydrous oxides in concentrated $\mathrm{NaHCO}_{3}$ and $\mathrm{Na}_{2} \mathrm{CO}_{3}$ solutions, Mater. Res. Soc. Symp. Proc. 353 (1995), pp. 1143-1150.

[29]Y. Xia, L. Rao, D. Rai and A.R. Felmy, Solvent extraction study of $\mathrm{Np}(\mathrm{IV})$ sulfate complexation in $\mathrm{Na}^{+}-\mathrm{Np}^{4+}-\mathrm{OH}^{-}-\mathrm{SO}_{4}{ }^{2-}-\mathrm{HSO}_{4}{ }^{-}-\mathrm{CIO}_{4}{ }^{-}$and $\mathrm{Na}^{+}-$ $\mathrm{Np}^{4+}-\mathrm{OH}^{-}-\mathrm{SO}_{4}{ }^{2-}-\mathrm{HSO}_{4}^{-}-\mathrm{Cl}^{-}$systems, Radiochim. Acta 86 (1999), pp. 33-40.

[30]D. Rai, Y. Xia, L. Rao, N.J. Hess, A.R. Felmy, D.A. Moore and D.E. McCready, Solubility of $\left(\mathrm{UO}_{2}\right)_{3}\left(\mathrm{PO}_{4}\right)_{2} \cdot 4 \mathrm{H}_{2} \mathrm{O}$ in $\mathrm{H}^{+}-\mathrm{Na}^{+}-\mathrm{OH}^{-}-\mathrm{H}_{2} \mathrm{PO}_{4}-\mathrm{HPO}_{4}{ }^{2-}-\mathrm{PO}_{4}{ }^{3-}-\mathrm{H}_{2} \mathrm{O}$ and its comparison to the analogous $\mathrm{PuO}_{2}^{2+}$ system. $J$. Solution Chem. 34 (2005), 471-501.

[31]D. Rai, Y.A. Gorby, J.K. Fredrickson, D.A. Moore and M. Yui, Reductive dissolution of $\mathrm{PuO}_{2}(\mathrm{am})$ : The effect of $\mathrm{Fe}(\mathrm{II})$ and hydroquinone. J. Solution Chem. 31 (2002), pp. 433 - 453.

[32]D. Rai, J.L. Swanson and J.L. Ryan, Solubility of $\mathrm{NpO}_{2} * \mathrm{xH}_{2} \mathrm{O}(\mathrm{am})$ in the presence of $\mathrm{Cu}(\mathrm{I}) / \mathrm{Cu}(\mathrm{II})$ redox buffer, Radiochim. Acta 42 (1987), pp. $35-41$.

[33]D. Rai and J.L. Swanson, Properties of plutonium (IV) polymer of environmental importance. Nucl. Technol. 54 (1981) pp. 107-112.

[34]D. Rai, J.A. Schramke, D.A. Moore and G.L McVay, Americium concentrations in solutions contacting Am-doped glass. Nucl. Technol. 75 (1986), pp. 350-355.

[35]H.R. Cho, C. Walther, J. Rothe, V. Neck, M.A. Denecke, K. Dardenne and Th. Fanghänel, Combined LIBD and XAFS investigation of the formation and structure of $\mathrm{Zr}(\mathrm{IV})$ colloids. Anal. Bioanal. Chem. 383 (2005) pp. 28-40.

[36]D. Rai, R.J. Serne and D.A. Moore, Solubility of plutonium compounds and their behavior in soils.
Soil Sci. Soc. Am. J. 44 (1980), pp. 490-495.

[37]D. Rai, M. Yui, H.T. Schaef and A. Kitamura, Thermodynamic model for $\mathrm{SnO}_{2}$ (cr) and $\mathrm{SnO}_{2}$ (am) solubility in the aqueous $\mathrm{Na}^{+}-\mathrm{H}^{+}-\mathrm{OH}^{-}-\mathrm{Cl}^{-}-\mathrm{H}_{2} \mathrm{O}$ system. J. Solution Chem. 40 (2011) pp. 1155-1172.

[38]D. Rai, A. Kitamura, K.M. Rosso, T. Sasaki and T. Kobayashi, Issues concerning the determination of solubility products of sparingly soluble crystalline solids: Solubility of $\mathrm{HfO}_{2}$ (cr). Radiochim. Acta 104 (2016), pp. 583-592.

[39]D. Rai, D.A. Moore, K.M. Rosso, A.R. Felmy and H. Bolton, Jr., Environmental mobility of Pu(IV) in the presence of ethtylenediaminetetraacetic acid: Myth or reality, J. Solution Chem. 37 (2008) pp. $957-986$.

[40]P.L. Brown, E. Curti and B. Grambow, Chemical Thermodynamics of Zirconium, Elsevier B. V., Amsterdam, (2005)

[41]H. Bilinski, M. Branica and L.G. Sillén, Precipitation and hydrolysis of metallic ions II. Studies on the solubility of zirconium hydroxide in dilute solutions and in $1 \mathrm{M} \mathrm{NaClO}_{4}$, Acta Chem. Scand. 20 (1966) pp. 853-861.

[42]A. Veyland, Propriétés thermodynamiques, cinétiques et structurales de complexes simples et mixtes du zirconium(IV) avec les ions hydroxyle et carbonate, Univ. of Reims Champagne-Ardenne, (1999).

[43]D. Rai, Y. Xia, N.J. Hess, D.M. Strachan and B.P. McGrail, Hydroxo and chloro complexes/ion-interactions of $\mathrm{Hf}^{4+}$ and the solubility product of $\mathrm{HfO}_{2}(\mathrm{am})$, J. Solution Chem. 30 (2001), 949-967.

[44]D.I. Ryabchikov, I.N. Marov, A.N. Ermakov and V.K. Belyaeva, Stability of some inorganic and organic complex compounds of zirconium and hafnium. J. Inorg. Nucl. Chem. 26 (1964), pp. 965-980.

[45]P.N. Kovalenko and K.N. Bagdasarov, The solubility of zirconium hydroxide. Russ. J. Inorg. Chem. 6 (1961), pp. 272-275.

[46]C. Ekberg, G. Källvenius, Y. Albinsson and P.L. Brown, Studies on the hydrolytic behavior of zirconium(IV), J. Solution Chem. 33 (2004) pp. 47-79.

[47]I.A. Sheka and T.V. Pevzner, Solubility of zirconium and hafnium hydroxides in sodium hydroxide solutions. Russ. J. Inorg. Chem. 5 (1960) pp. 1119-1121.

[48]T. Amaya, T. Chiba, K. Suzuki, C. Oda, H. Yoshikawa and M. Yui, Solubility of Sn(IV) oxide in dilute $\mathrm{NaClO}_{4}$ solution at ambient temperature. Mater. Res. Soc. Symp. Proc. 468 (1997), pp. 751-758.

[49]D. Rai and A. Kitamura, Thermodynamic equilibrium constants for important isosaccharinate reactions: A review. J. Chem. Thermodyn. 114 (2017), pp.135-143. 